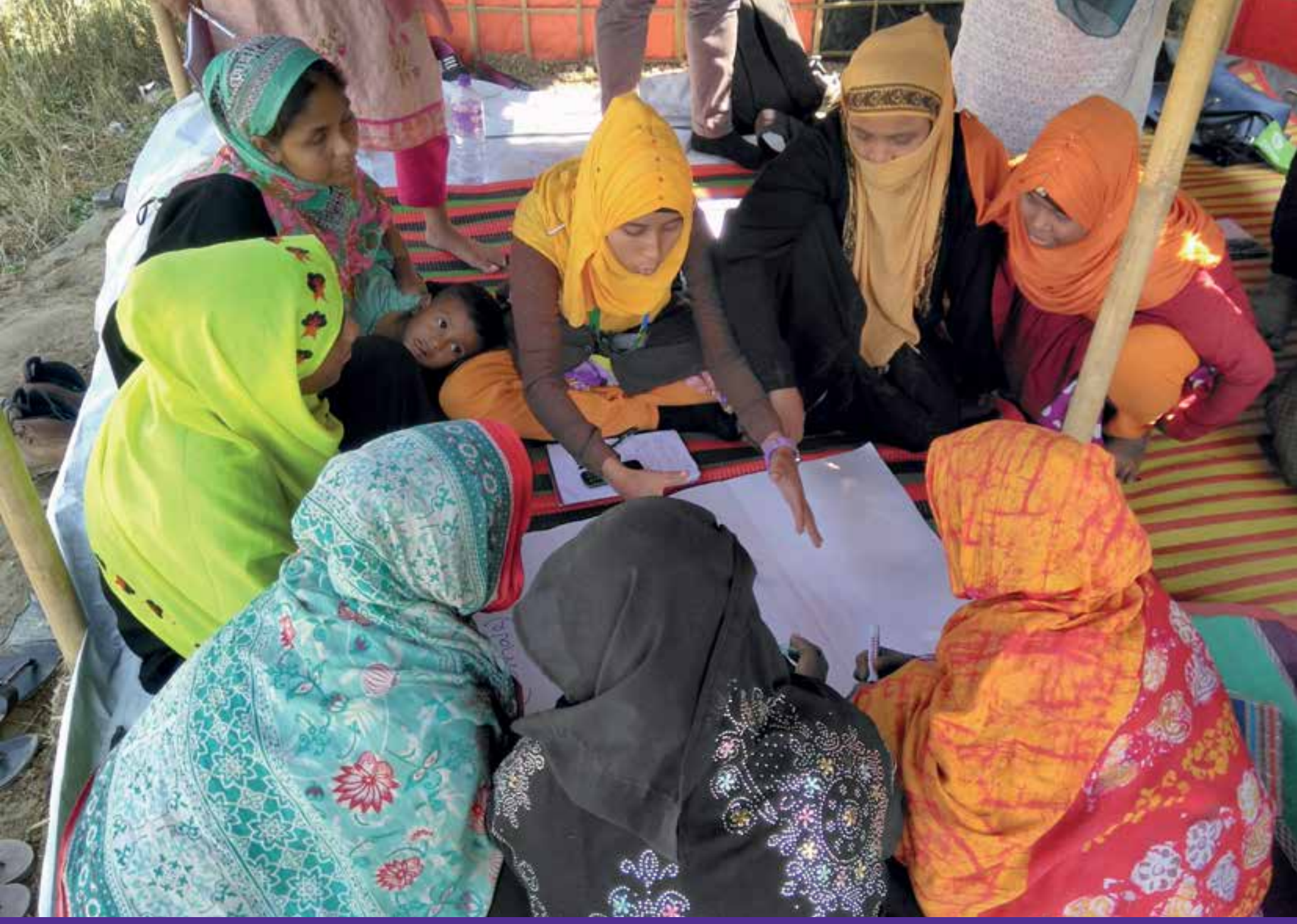

\title{
AN INTRODUCTION TO COMMUNITY ENGAGEMENT IN WASH
}

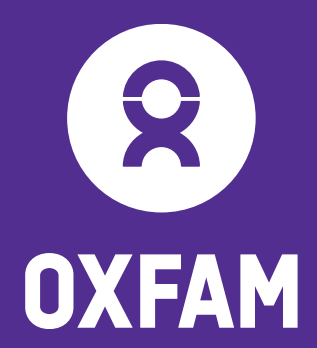





\section{AN INTRODUCTION TO COMMUNITY ENGAGEMENT IN WASH}

The humanitarian sector has been strengthening its focus on and commitment to community-centred responses in recent years. ${ }^{1}$ This guide aims to provide field staff with clear, accessible guidance on the principles and practice of community engagement in WASH programmes. The content has been field tested in a variety of contexts.

The principles and approaches described here are relevant in other programmes and sectors too, but the target audience for this guide is WASH staff in humanitarian programmes - especially those responsible for designing, implementing and monitoring public health promotion activities. It will also be relevant for managers, public health engineers and decision makers interested in promoting good quality outcomes in WASH programmes by ensuring that communities affected by crisis are at the centre of the response.

\section{Contents}

1 What is community engagement in WASH? 4

2 Some guiding principles for community engagement in WASH 6

$3 \mathrm{~A}$ model of community engagement for programme design and implementation 8

4 Community engagement: a continuous process of handing over control 13

5 Measuring community engagement 16

$\begin{array}{ll}\text { Annex } 1 & 18\end{array}$

$\begin{array}{lr}\text { Annex } 2 & 20\end{array}$

Annex $3 \quad 24$ 


\section{WHAT IS COMMUNITY ENGAGEMENT IN WASH?}

Oxfam's WASH response in emergencies aims to reduce the increased risks to health that people affected by emergencies can face in relation to water, sanitation and hygiene and disease outbreaks.

Community engagement in WASH is a planned and dynamic process to connect communities and other emergency response stakeholders to increase community's control over the impact of the response. It brings together the capacities and perspectives of communities and responders. Effective community engagement encompasses other sectors and response teams within Oxfam and across the humanitarian sector more broadly. However, this document focuses on maximizing community influence on and acceptance of WASH, so that:

- Public health risks are reduced;

- Communities' right to be involved in decision making is upheld, through honest dialogue and the provision of clear information;

- Programme quality is strengthened through good communication, participation and feedback (Quality Criterion 4 of the Core Humanitarian Standard);

- The programme is adapted to the evolving emergency, based on this feedback and on the needs and preferences of affected communities;

- Community acceptance and mutual trust underpins programme activities - particularly important in insecure contexts.

Listening to different groups and individuals is key to community engagement. Understanding how people view risk and how they cope in a crisis can help to ensure that as far as possible, the WASH response strengthens their existing capacities, enables meaningful participation and focuses in particular on marginalized and less powerful members of a community. 


\section{What is a community?}

A community is a group of people who have something in common. This could be through their proximity, or social relationships, shared interests, identity or values. We often refer to the 'affected community' in an emergency, but the only thing people may share in common is the emergency itself. Communities are diverse, dynamic and often complexand in emergencies, usual social norms and practices can change. Our interventions may both strengthen and undermine community connectedness - so how can we start to see the situation from the different perspectives of those who are affected, and begin to build relationships with them based on trust and accountability?

\section{When you visit communities:}

- Be sure that your behaviour is in line with Oxfam's Code of Conduct

- Dress appropriately and wear identification

- Ask permission from local leadership

- Provide information on who you are and what you are doing

- Plan community meetings in advance where possible

- Show courtesy and patience

- Do not take photographs without permission

- Consult women and men separately

- Work with translators where required

See WASH Accountability checklist and resources for more information: http://violence-wash.lboro.ac.uk/vgw/Supporting-documents/

VGW-5-Good-practice-Violence-WASH-Emergencies/WASH-Cluster-WASHaccountability-handbook.pdf 


\section{SOME GUIDING PRINCIPLES FOR COMMUNITY ENGAGEMENT IN WASH}

- Be aware of our own attitudes and behaviour: we too are influenced by our background and culture, so avoid making assumptions and work hard to understand different perspectives. As soon as possible, find staff or partners who know the local language and culture to act as mediators.

- Communities are diverse: understanding community structures and dynamics and how these affect women and men, individuals and groups differently is especially important for ensuring that marginalized people are able to influence the programme. Think about getting specialist help from a sociologist or anthropologist to support this.

- Recognize and build on local knowledge and skills as much as possible. Create opportunities for the meaningful participation of affected women and men in all stages of the work. This means enabling them to have more control over decisions which affect them. Try to find ways to measure participation - it is more likely to be effectively managed if it is measured.

- Provide practical information in accessible language about your organization and partners and the programme, and link people to other services and responding agencies where that is helpful.

- Find good translators where necessary to ensure that everyone can be involved with the programme.

- Encourage feedback on the quality and effectiveness of the response from different members of the community, especially the more vulnerable and marginalized people.

- Communication is most effective as a two-way process. Use feedback to adapt your programme to the evolving context and to influence the interventions of other actors too, where appropriate.

- Support collaboration and coordination within and between sectors to achieve an integrated, people-centred response. As far as possible, share information and work together with others to develop coherent and appropriate ways of approaching and working with communities.

- Advocate for community concerns and priorities to be addressed by other actors or sectors where appropriate. Lobby within your own organization for the skills and resources to enable good quality community dialogue as early as possible in the response. 


\section{Advocating and coordinating}

During the Ebola response in DRC in August 2018, many communities in conflict-affected areas did not initially believe that Ebola could pose a serious risk to their families, compared with the usual threats they faced every day, living in insecure areas. Oxfam listened to their concerns and suspicions, shared the analysis of this information with the coordination platforms and helped to put people in touch with the support services such as the vaccination and burial teams which were provided by other agencies.

\section{How do the communities we work with see us?}

Is 'one Oxfam' listening to them ... or are there a number of teams with different agendas?

During Oxfam's response to the Nepal earthquake in 2015, the WASH, emergency food security and vulnerable livelihoods, and shelter teams each used different selection criteria to target households. The reasons for this were not always well understood by communities. In some locations, the WASH and EFSVL teams were working with the same partner, whose community mobilizers struggled to participate in poorly coordinated meetings organized by Oxfam. 


\section{A MODEL OF COMMUNITY ENGAGEMENT FOR PROGRAMME DESIGN AND IMPLEMENTATION}

This model was designed for an Oxfam disease outbreak response. It can be applied and adapted to other WASH programmes and adapted to other WASH programmes.

The model puts community engagement at the centre of the Oxfam WASH programme, and links communities to other emergency response stakeholders through coordination and advocacy mechanisms. It is not intended to be used as a standard template for programming, but taken together, all of these components contribute to maximizing the influence of affected communities over positive outcomes in emergency WASH responses. 
FIGURE 1: WHAT DOES COMMUNITY ENGAGEMENT LOOK LIKE IN THE PROGRAMME YOU ARE WORKING IN?

\section{THE CONTEXT}

Type and location of the emergency; response actors and institutions; EPI data for PH risk analysis; status of WASH infrastructure; food, livelihood and protection analysis

\section{THE PEOPLE}

Demography; leadership

structures; gender and power dynamics; history; education; religion; ethnicity; influential individuals/groups

\section{ADVOCACY}

For WASH and other

community priorities

COORDINATION AND

COLLABORATION

With national, international and local actors to influence decision making

CAPACITY BUILDING

For staff, partners and communities

\section{THEIR BEHAVIOUR AND PRACTICE}

Before emergency and now: ways of coping, norms and beliefs; myths and rumours? Knowledge of risks/ prevention compared with practice; access/use of services; motivation for positive change in behaviour and practice

\section{INFORMATION AND COMMUNICATION \\ Must be: practical, appropriate for context, delivered through diverse channels, on access to services and reducing risk}

\section{PARTICIPATION}

Work in partnership to increase community ownership, decision making and control over processes, facilities and services

MONITORING, EVALUATION AND LEARNING

Feedback loop: analyse monitoring data, share with communities and agree adaptations to programme where possible 


\section{Information and analysis for programme planning and design}

In Figure 1, the top three boxes describe the information and analysis needed to develop a good understanding of the emergency context, the affected population and their behaviours and practices. Rapid assessments will focus initially on the context, the level of risk to local communities and the presence or absence of other humanitarian actors, to enable quick decisions about whether and how Oxfam and its partners should respond. More detailed information about affected communities and their priorities, behaviours and practice will then be needed to design the response. Some of this information may be available as secondary data (Oxfam country strategies, studies and reports from national or international organizations) - but much of it will need to be collected and regularly updated through community meetings, focus group discussions and interviews with different members of the community.

The context: This data comes from Oxfam's and partners' own assessments and information, shared through coordination mechanisms. It should ideally be shared and analysed together with EFSVL, gender and protection colleagues so that decisions about the response are based on a holistic understanding of risk and need and the capacities and vulnerabilities of the population affected by the emergency. In disease outbreaks, it is especially important to access epidemiological data so that the WASH response is flexible enough to react to trends in disease transmission and 'hot spots'.

The people: Develop a profile of the community. An initial estimation of gender and age breakdown can be refined later when data can be disaggregated. Build up a picture of formal and informal leadership structures and power dynamics, socio-cultural factors which may influence beliefs and perspectives, community groups and organizations which can be supported/strengthened, and those individuals or groups who are vulnerable or marginalized. Who are the people who influence others through their formal authority e.g. government officials, teachers, religious leaders, etc.? What is their informal influence on behaviour and practice, for example, traditional healers or individuals respected by their community for their knowledge and wisdom?

Behaviour and practice: Telling people what to do is rarely useful on its own. Knowledge, attitude and practice (KAP) studies may provide information on what they know and do, but not usually on why - and in most countries, there is a gap between what people say they do and what they actually do. Understanding why this is and what influences people's preferences is important. If individuals could benefit from changing their behaviour, or the community from agreeing on collective action, how can we engage with them to motivate change? What are they already doing to resolve some of their problems, and can we support them to build on this? 


\section{Programme implementation}

Information and communication are at the heart of community engagement. Individuals and communities will need practical information, communicated clearly in the local language, to understand their entitlements and to help them make informed choices. A range of channels should be used. Mass media - for example through local radio, traditional folklore, social media, information/picture boards - can make information widely accessible and inclusive of vulnerable and marginalized people. But research also shows that people need to relate the information to their real lives through discussing and questioning, so opportunities for face-to-face dialogue are vital.

Community participation: Meaningful participation involves more than community contributions of labour, skills or time, or the use of participatory approaches. It is defined here as a flexible, inclusive and collaborative process, bringing together local and Oxfam/partner perspectives and resources, enabling communities to shape the programme so that it works for them. It can promote dignity through ensuring that people are not simply passive recipients of aid but are actively involved in problem solving, planning and decision making - and as far as possible, owning responsibility for programme process, facilities and services. Measuring participation will help us to ensure that it is managed effectively.

Monitoring, evaluation, accountability and learning (MEAL): As early as possible in the response, we need to set up mechanisms for listening to people describe how the emergency is affecting their lives and whether our programme and the broader response is making a difference to them. The programme should be adapted in line with feedback from monitoring data or complaints, and the changes made reported back to affected communities as part of our commitment to be accountable to them. Staff, partners or volunteers should never demand favours or payment in return for WASH services. Oxfam's Safeguarding Policies ${ }^{2}$ provide guidance on measures for preventing and reporting such abuse of power.

Capacity building on the job, through coaching and mentoring or through appropriate training can enhance staff, partners' and communities' capacity to engage with the programme and potentially, to build skills and capacity for future preparedness and response.

As far as possible, we should work through existing groups or structures rather than setting up parallel processes which may undermine them.

Advocacy: Collaboration, good listening and effective monitoring is likely to highlight 
community concerns which cannot be addressed within the scope of our own programme alone, so it is important to lobby team leaders and managers to ensure that community voices and priorities are raised through coordination mechanisms at all levels. Resourcing WASH teams may be an issue for internal advocacy. Good community dialogue will pay dividends for programme quality and community satisfaction, and needs skilled staff available who can focus on this from the start.

Coordination and collaboration: Community engagement in Oxfam's and partners' programmes may be influenced by financial and policy decisions made by other humanitarian actors or institutions, based on funding priorities, targeting, government standards, and mass communications, for example. The impact of these decisions needs to be fed back to the decision makers at the appropriate local, national or international level with evidence of the impact on communities to support this. At the technical level, coordinating with others on strategies to address context-specific technical challenges provides openings for sharing experience and influencing others. 


\section{COMMUNITY ENGAGEMENT: A CONTINUOUS PROCESS OF HANDING OVER CONTROL}

A key element of community engagement is that it enables people to have a say in decision making wherever possible. Figure 2 represents it as a continuous process reflecting the relationship between affected communities and humanitarian response actors (Oxfam/partners/other agencies). Different levels of engagement may be practical or appropriate at different stages in the response e.g. the first phase, or later when things have stabilized - or they may happen simultaneously. The context will also play its part: what is possible in a conflict situation may be different from opportunities in a protracted crisis or natural disaster.

Ask yourself: Where is my programme in this continuous process ... and can we hand over more control to communities?

FIGURE 2: THE RELATIONSHIP BETWEEN AFFECTED COMMUNITIES AND HUMANITARIAN RESPONSE WORKERS - A CONTINUOUS PROCESS

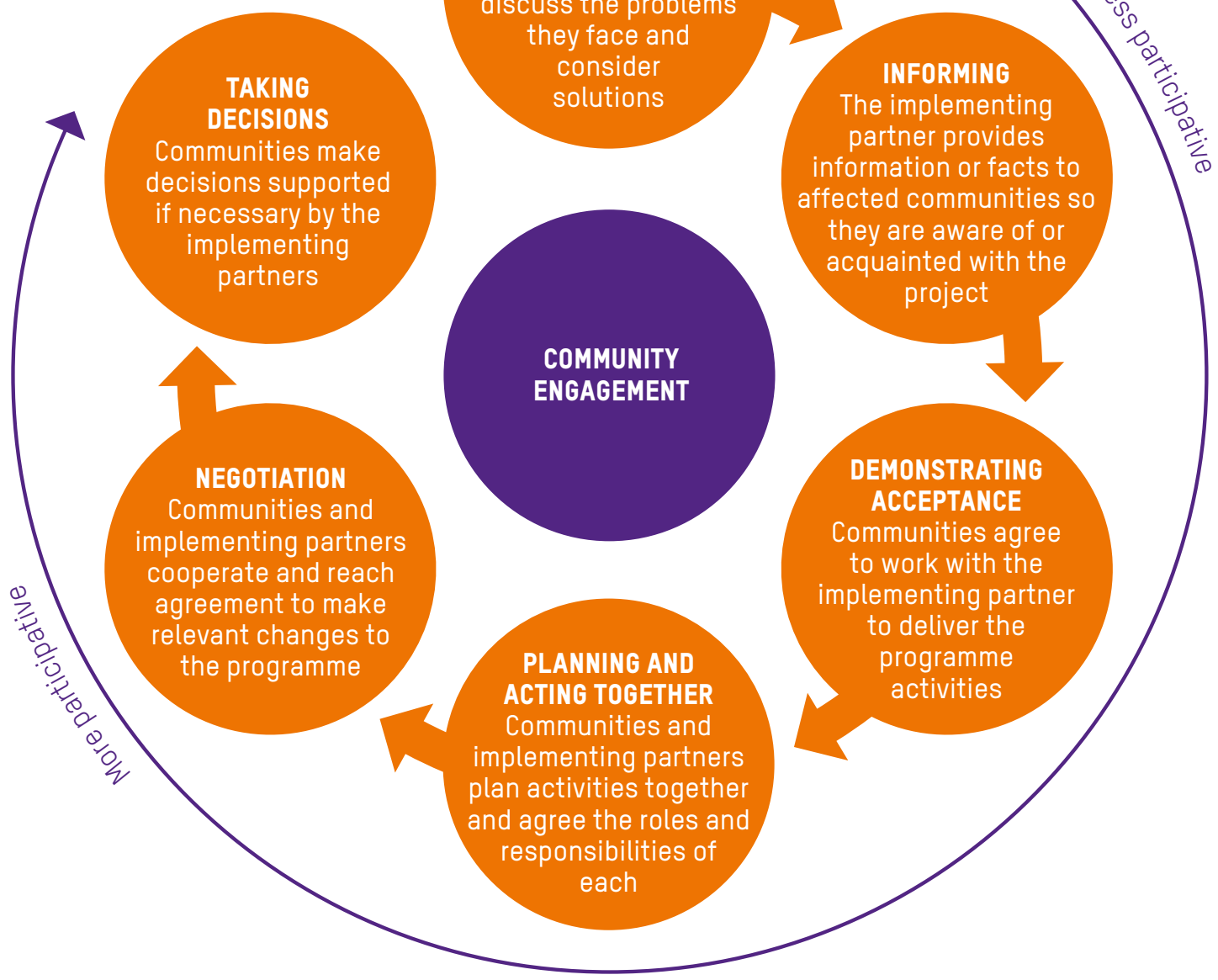




\section{What influences peoples' decisions to change their behaviour or practice?}

In emergency WASH, our primary concern is to reduce public health risks. Sometimes, this means that people may have to change their current behaviours and practices or adopt new ones that will reduce these risks. In the context of WASH, 'behaviours' mean things like accessing water from an unsafe source, practicing open defecation or washing hands at key times to prevent disease transmission.

Giving people information about risks to health will not always mean that they take action to prevent them - knowledge doesn't always lead to change. The reasons for this are complex. Social norms, perceptions of risk, and the availability of resources can all influence whether certain positive changes are adopted. Figure 3 outlines a five-step process for designing activities to change behaviour and practice.

FIGURE 3: A FIVE-STEP PROCESS FOR DESIGNING ACTIVITIES TO CHANGE BEHAVIOUR AND PRACTICE

ASSESS AND PRIORITIZE PUBLIC HEALTH RISKS
Continuously assess and prioritize risks to public health as they relate to
the following areas: 1 Excreta disposal; 2 Handwashing with soap;
3 Water access and quality at household level
STEP 1


First, before beginning PHP activities, work with the communities affected by the emergency to assess the public health risks they are facing. Next, we need to understand their current behaviours and practices as they relate to these risks. For example, if contaminated water poses a threat to health, we need to understand where people access their water and how they treat it at the household level. For those who are using water from an unsafe source, or are not treating their water at the household level, we need to explore the reasons for this in more detail.

Once we know what people are doing and why they are doing it, we can begin to develop our understanding of motivators and barriers: what stops people adopting positive behaviours and practices, and what would motivate or enable them to make changes? Do they need more information about risks or how to access facilities and services? Do we need to provide more or better WASH facilities or help with access to non-food items? Or find creative ways of motivating change, for example by using non-health motivators to increase the uptake of hand washing. We may need to do a combination of these things depending on the context.

Lastly, it is important to track progress by monitoring activities and getting feedback from communities, so that the programme can be modified accordingly. As the situation evolves, make sure that activities are adapted so that they remain relevant. 


\section{MEASURING COMMUNITY ENGAGEMENT}

\section{Indicators and tools}

Participatory approaches to working with communities are often used in emergency WASH, but Oxfam does not have a structured way of measuring how effective they are in achieving WASH outcomes. We need to change this because:

- Affected populations have a right to participate in decisions which affect them. Measuring participation can help to ensure that it is managed effectively;

- Knowing what works (or what doesn't work) and why, is vital for learning how to adapt ways of working in diverse contexts;

- Using common indicators for community engagement and participation, adapted for the context, will enable comparison across programmes;

- Evidence of effectiveness is important in order to plan cost-effective interventions, influence others and lobby for resources to deliver community-centred activities at scale.

\section{Measuring community engagement in emergency WASH programmes}

The overall objective of an emergency WASH programme is to achieve a reduction in public health risk. WASH outcomes are measured as part of the programme MEAL plan and are generally used as an alternative or proxy for impact. So, access to, and use of WASH facilities and services is measured and compared with information on WASH-related disease trends.

Community involvement at all stages of the programme cycle is an essential right for people affected by emergencies (Core Humanitarian Standards Commitment 4) and plays a vital role in achieving positive WASH outcomes. Measuring community participation in, and satisfaction with the WASH programme will help us to manage the way we engage with communities for maximum impact on their health and wellbeing.

A 'good enough' monitoring plan with indicators for measuring community participation and user satisfaction with WASH facilities and services should be developed as soon as possible within the first four to six weeks of the response. 


\section{Tools for including community perspectives}

Annex 1 contains a table of indicators for WASH outcomes: what has been achieved; process indicators for community participation to help measure how we worked with communities to achieve the outcomes; and indicators for community satisfaction - to what extent people felt that they were listened to and their perspectives appreciated. Annex 2 contains examples of two other tools: Spidergrams, which can be used for measuring community participation and satisfaction, and Venn diagrams for facilitating discussions on community dynamics.

Annex 3 gives examples of suggested activities and time frames for community engagement in WASH. 


\section{ANNEX 1}

TABLE 1: MATRIX OF INDICATORS FOR MEASURING COMMUNITY PARTICIPATION AND SATISFACTION IN RELATION TO WASH IN THE INITIAL 4 TO 6 MONTHS OF RESPONSE

\begin{tabular}{|c|c|c|}
\hline WASH & Community participation & Community satisfaction \\
\hline $\begin{array}{l}\text { - There is no evidence of } \\
\text { WASH-related disease } \\
\text { outbreaks } \\
\text { - Access to appropriate } \\
\text { WASH facilities and } \\
\text { resources is available to } \\
\text { all in line with Sphere } \\
\text { standards } \\
\text { - WASH facilities are } \\
\text { consistently used and } \\
\text { users are involved in } \\
\text { maintaining them } \\
\text { - There is no evidence of } \\
\text { open defecation } \\
\text { - Safe water chain is } \\
\text { maintained } \\
\text { - Hand washing is } \\
\text { effectively practised }\end{array}$ & $\begin{array}{l}\text { - Formal and informal } \\
\text { community leaders, } \\
\text { community organizations } \\
\text { and institutions are } \\
\text { identified } \\
\text { - A stakeholder map } \\
\text { developed with } \\
\text { communities is used to } \\
\text { analyse power dynamics } \\
\text { and for programme } \\
\text { planning } \\
\text { - A diverse range of people } \\
\text { selected by the } \\
\text { community is involved in } \\
\text { decisions on the } \\
\text { planning, design and } \\
\text { maintenance of WASH } \\
\text { infrastructure and } \\
\text { services } \\
\text { - Communities, including } \\
\text { more marginalized } \\
\text { groups, influence the } \\
\text { design of feedback and } \\
\text { complaints mechanisms } \\
\text { - There is evidence that } \\
\text { cultural and religious } \\
\text { beliefs are incorporated } \\
\text { into programme design }\end{array}$ & $\begin{array}{l}\text { - Communities report that } \\
\text { key information is clearly } \\
\text { communicated in } \\
\text { appropriate languages } \\
\text { and reaches all sections } \\
\text { of the community using } \\
\text { context-specific } \\
\text { channels } \\
\text { - Communities report that } \\
\text { specific gendered needs } \\
\text { of women and men, boys } \\
\text { and girls are taken in to } \\
\text { account in the design and } \\
\text { location of the facilities } \\
\text { laccess, privacy, safety, } \\
\text { menstrual hygiene } \\
\text { management-friendlyl } \\
\text { - Communities express } \\
\text { satisfaction that their } \\
\text { feedback has listened to } \\
\text { and changes have been } \\
\text { made in the programme } \\
\text { where possible } \\
\text { - Marginalized groups and } \\
\text { individuals express } \\
\text { satisfaction with } \\
\text { consultation and } \\
\text { programme adaptations }\end{array}$ \\
\hline
\end{tabular}




\begin{tabular}{|c|c|c|}
\hline WASH outcomes & Community participation & Community satisfaction \\
\hline & $\begin{array}{l}\text { - Diverse community } \\
\text { members are included in } \\
\text { identifying local priorities, } \\
\text { problems and their own } \\
\text { solutions } \\
\text { - Implementation plan with } \\
\text { roles and responsibilities } \\
\text { of all actors is agreed and } \\
\text { monitored } \\
\text { - Community members are } \\
\text { involved in monitoring } \\
\text { programme activities and } \\
\text { in the feedback loop to } \\
\text { their wider community } \\
\text { - Communities are } \\
\text { supported to advocate on } \\
\text { their behalf to Oxfam and } \\
\text { to other stakeholders } \\
\text { through coordination } \\
\text { platforms } \\
\text { - Capacity development } \\
\text { and a timely exit/ } \\
\text { transition plan is agreed } \\
\text { by communities and other } \\
\text { key stakeholders }\end{array}$ & $\begin{array}{l}\text { - Communities report that } \\
\text { they have the skills and } \\
\text { support to manage WASH } \\
\text { facilities and services }\end{array}$ \\
\hline
\end{tabular}




\section{ANNEX 2}

Spidergrams are visual tools which are used to facilitate discussions with communities (or programme teams) on the participation process, by encouraging them to consider how and why change happens within a programme. It can also be used to monitor change compared to a baseline e.g. on communities' perceptions on whether the programme is being adapted in line with their feedback, or on their levels of satisfaction with specific elements of the programme. Figures 4 and 5 use indicators from Table 1 to measure community participation and community satisfaction with the WASH programme.

The indicators are ranked from 1 to 5 along the legs of the spider and the changes from baseline to follow-up are represented by the dotted and solid lines. 
FIGURE 4: SPIDERGRAM - COMMUNITY SATISFACTION

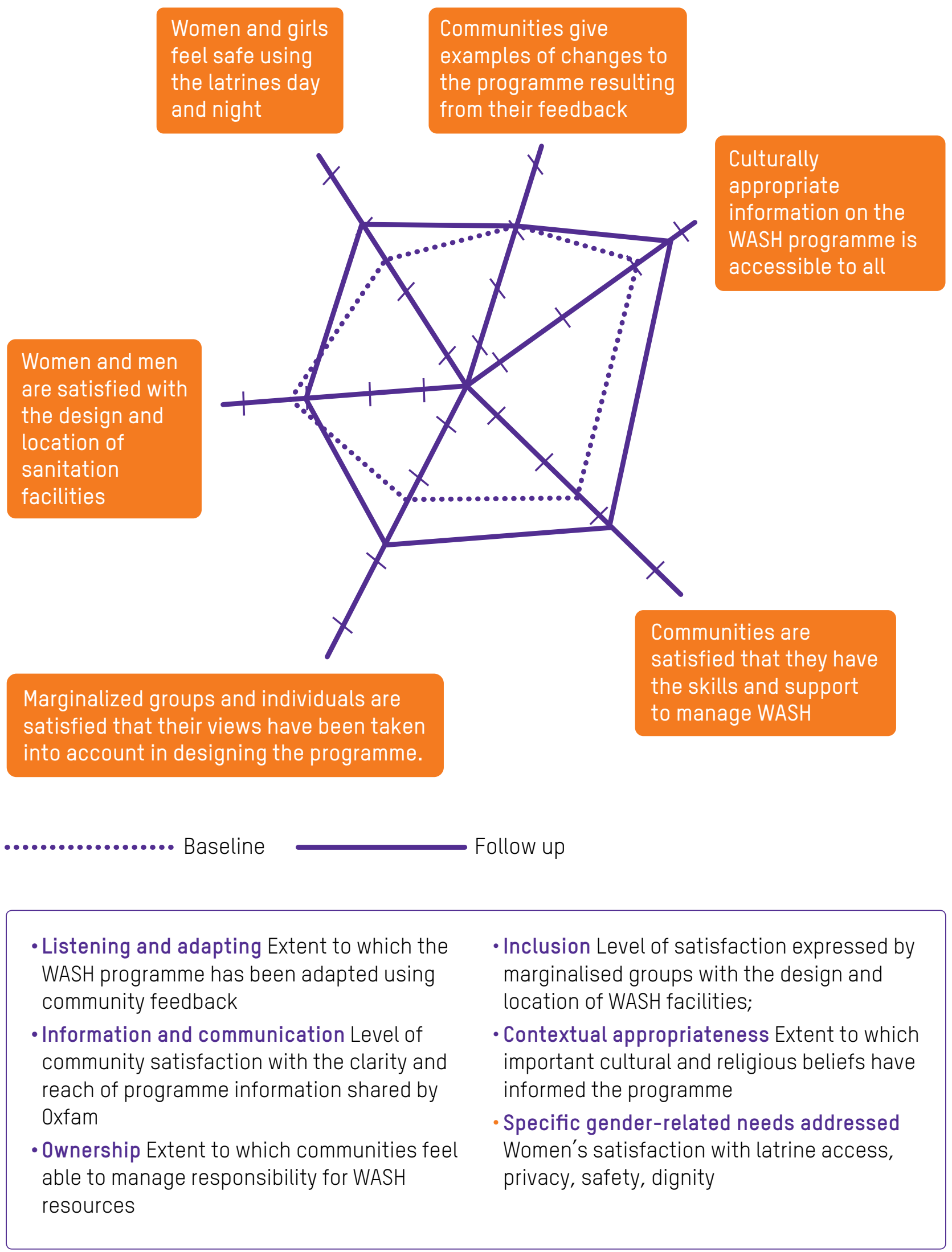




\section{FIGURE 5: SPIDERGRAM - COMMUNITY PARTICIPATION INCLUSION AND DIVERSITY}

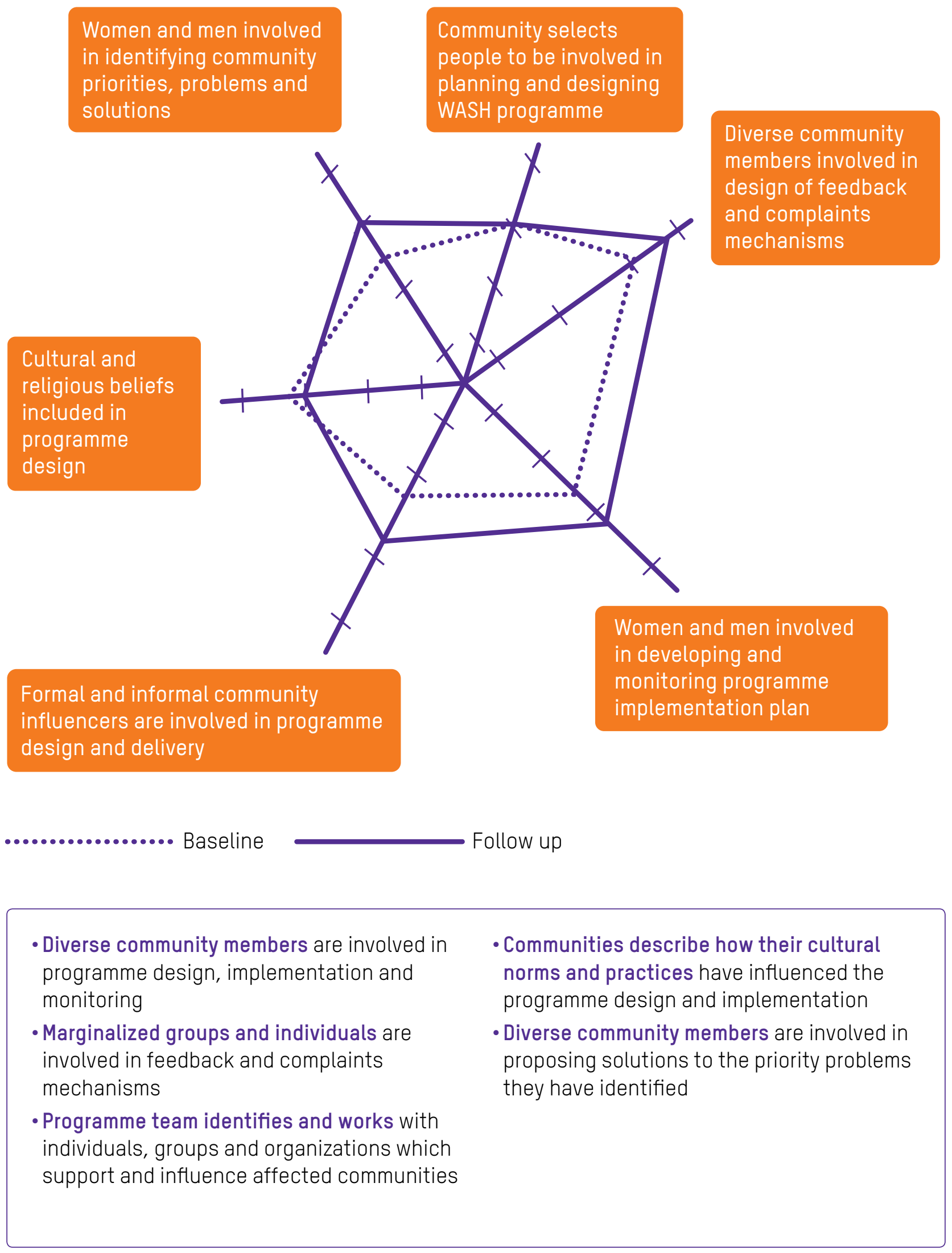


A Venn diagram uses circles to illustrate the extent to which individuals, institutions and groups interact with each other. The varied size of the circles can indicate the importance of different stakeholders to the community in relation to power, dependency or the potential for working together.

FIGURE 6: VENN DIAGRAM TO SHOW COMMUNITY INTERACTIONS

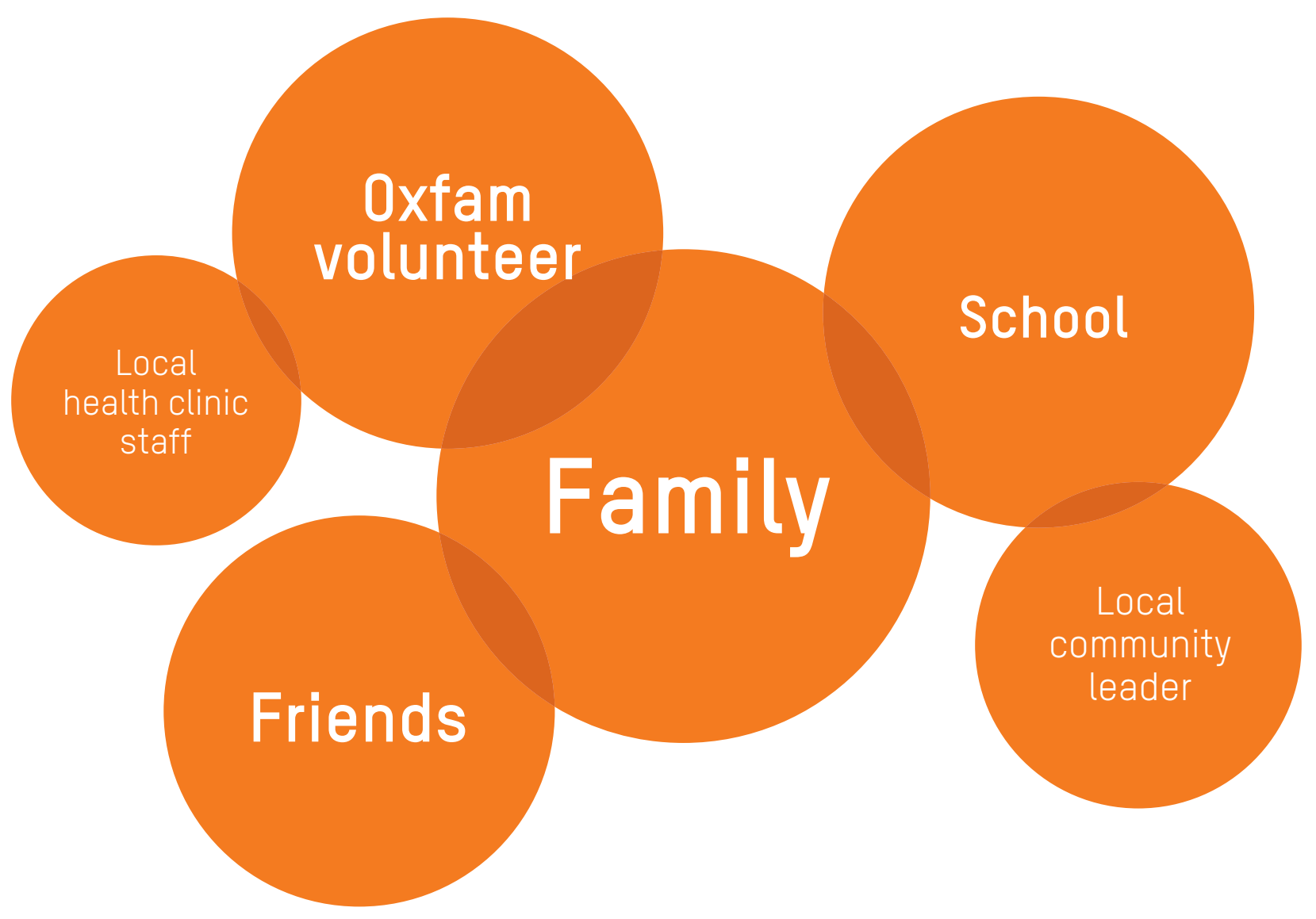




\section{ANNEX 3}

TABLE 2: SUGGESTED ACTIVITIES AND TIME FRAMES

\begin{tabular}{|c|c|c|}
\hline Time frame & CE objective & Suggested key activities \\
\hline $\begin{array}{l}\text { Weeks 1-4 } \\
\text { - Rapid needs and } \\
\text { capacity } \\
\text { assessment } \\
\text { - Community } \\
\text { profiling }\end{array}$ & $\begin{array}{l}\text { - Lay foundations } \\
\text { for community } \\
\text { engagement }\end{array}$ & $\begin{array}{l}\text { - Undertake basic stakeholder analysis to } \\
\text { understand who in the community we should } \\
\text { talk to: who are the gatekeepers (formal } \\
\text { stakeholders) and informal leaders? How can } \\
\text { we reach vulnerable and less visible groups? } \\
\text { - Provide information for communities on risk } \\
\text { and access to services } \\
\text { - Identify critical religious or cultural issues } \\
\text { and follow up on assessment for more in- } \\
\text { depth analysis } \\
\text { - Set up 'good enough' feedback mechanisms } \\
\text { - Recruit local staff/partners and carry out } \\
\text { rapid training on community engagement }\end{array}$ \\
\hline
\end{tabular}




\begin{tabular}{|c|c|c|}
\hline Time frame & CE objective & Suggested key activities \\
\hline $\begin{array}{l}\text { Months 2-3 } \\
\text { - Strengthen } \\
\text { inclusion and } \\
\text { vulnerability } \\
\text { analysis - who } \\
\text { has been } \\
\text { missed? } \\
\text { - Identify gaps in } \\
\text { the response }\end{array}$ & $\begin{array}{l}\text { - Strengthen the } \\
\text { dialogue - } \\
\text { deepen } \\
\text { understanding } \\
\text { of community } \\
\text { perspectives } \\
\text { - Collect and } \\
\text { respond to } \\
\text { feedback }\end{array}$ & $\begin{array}{l}\text { - Map out who is consulted about what (social } \\
\text { mapping, Venn diagrams) } \\
\text { - Engage with the MEAL team and set up } \\
\text { listening groups: meet regularly with these } \\
\text { groups for feedback using a set of } \\
\text { exploratory questions to check Oxfam's/ } \\
\text { partner's assumptions; understand and build } \\
\text { on community coping strategies; inform } \\
\text { advocacy (share with coordination platforms } \\
\text { with permission) and ensure 2-way feedback } \\
\text { - How do communities perceive the evolving } \\
\text { situation? } \\
\text { Review WASH outcomes with colleagues in } \\
\text { conjunction with: } \\
\text { - Level of satisfaction with initial response? } \\
\text { - How should the programme be adapted? } \\
\text { - What has changed in the last month } \\
\text { (understanding of risk, people movements, } \\
\text { and seasonal changes)? } \\
\text { - What are community priorities for the next } \\
2 \text {-3 months among displaced and non- } \\
\text { displaced? } \\
\text { - Agree meaningful action plan with them if } \\
\text { appropriate } \\
\text { Look for examples of positive deviance }{ }^{3} \text { and } \\
\text { explore how engagement is playing out } \\
\text { differently across communities } \\
\text { Share learning across programme sites if } \\
\text { relevant. }\end{array}$ \\
\hline
\end{tabular}




\begin{tabular}{|c|c|c|}
\hline Time frame & CE objective & Suggested key activities \\
\hline $\begin{array}{l}\text { Months 4-6 } \\
\text { - Monitoring and } \\
\text { adapting } \\
\text { - Review evolving } \\
\text { risks in relation } \\
\text { to response }\end{array}$ & $\begin{array}{l}\text { - Enhance } \\
\text { listening and } \\
\text { community } \\
\text { engagement } \\
\text { skills of staff } \\
\text { and partners } \\
\text { - Enhance } \\
\text { capacity of } \\
\text { community to } \\
\text { manage/ } \\
\text { influence the } \\
\text { response }\end{array}$ & $\begin{array}{l}\text { - Review staff/partner listening and dialogue } \\
\text { - Ekills and enhance/update as necessary } \\
\text { - } \text { programme monitoring data is used to adapt } \\
\text { the programme - and that this is } \\
\text { documented } \\
\text { - Review community participation and } \\
\text { satisfaction indicators - update/amend with } \\
\text { community as necessary } \\
\text { - Review WASH outcomes with colleagues in } \\
\text { conjunction with feedback on community } \\
\text { participation and satisfaction - make } \\
\text { changes to programme if necessary } \\
\text { - Promote community involvement in } \\
\text { monitoring } \\
\text { - As part of exit discussions, review with } \\
\text { community their capacity to maintain and } \\
\text { manage WASH facilities, services and } \\
\text { processes } \\
\text { - Prepare for programme evaluation and review } \\
\text { of CHS commitments and quality criteria }\end{array}$ \\
\hline
\end{tabular}




\section{Notes}

${ }^{1}$ Sphere Project (2018). The Sphere Handbook: Humanitarian Charter and Minimum Standards in Humanitarian Response. https://spherestandards.org/wp-content/ uploads/Sphere-Handbook-2018-EN.pdf IASC (2017). Revised Accountability to Affected Populations Commitments. https://interagencystandingcommittee.org/accountability-affected-populationsincluding-protection-sexual-exploitation-and-abuse/documents-61

${ }^{2}$ Global WASH Cluster (2009). WASH Accountability Resources. http:/ /violence-wash. Iboro.ac.uk/vgw/Supporting-documents/VGW-5-Good-practice-Violence-WASHEmergencies/WASH-Cluster-WASH-accountability-handbook.pdf https://www.oxfam.org.uk/safeguarding-at-oxfam/safeguarding-related-policies

${ }^{3}$ Find out why some people adopt positive action or behaviour - how are they different to those who don't? Can this information be used to motivate others? 
For more information, or to comment on this guide, contact Eva Niederberger, Public Health Promotion/Community

Engagement, eva.niederberger[axfam.org

(C) Oxfam International December 2018

This publication is copyright but the text may be used free of charge for the purposes of advocacy, campaigning,

education, and research, provided that the source is acknowledged in full. The copyright holder requests that all such use be registered with them for impact assessment purposes. For copying in any other circumstances, or for re-use in other publications, or for translation or adaptation, permission must be secured and a fee may be charged. Email policyandpractice@oxfam.org.uk

The information in this publication is correct at the time of going to press.

Published by Oxfam GB for Oxfam International under ISBN 978-1-78748-389-7 in December 2018.

DOI: $10.21201 / 2018.3897$

Oxfam GB, Oxfam House, John Smith Drive, Cowley, Oxford, OX4 2JY, UK.

\section{Oxfam}

Oxfam is an international confederation of 19 organizations networked together in more than 90 countries, as part of a global movement for change, to build a future free from the injustice of poverty. Please write to any of the agencies for further information, or visit www.oxfam.org

Front cover: An Oxfam Public Health assistant facilitates a session with community-based volunteers, Unchiprang camp, Cox's Bazar, Bangladesh (2018). The group is planning actions in response to an outbreak of diphtheria.

Photo: Eva Niederberger/Oxfam

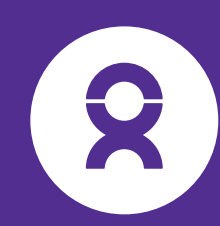

